\title{
Expression patterns of the immune checkpoint ligand CD276 in urothelial carcinoma
}

\author{
Wilhelm K. Aicher ${ }^{1,3^{*}}$, M. Korn', L. Reitnauer ${ }^{1}$, F. B. Maurer', J. Hennenlotter ${ }^{1}$, P. C. Black ${ }^{2}$, T. Todenhofer', \\ J. Bedke ${ }^{1}$ and A. Stenzl ${ }^{1}$
}

\begin{abstract}
Background: CD276 is an immune checkpoint molecule. Elevated CD276 expression by urothelial carcinoma is associated with poor prognosis, but little is known about its expression across different tumor stages. We therefore investigated CD276 expression in bladder cancer (BC) cells and in tissue samples of BC stages from pT2 to pT4.
\end{abstract}

Methods: CD276 expression was explored in 4 urothelial cancer cell lines and 4 primary normal urothelial cell populations by quantitative RT-PCR, Western blot and flow cytometry. CD276 was investigated in bladder tumors from 98 patients by immunohistochemistry using a score (0-300) incorporating both, staining intensity and area of CD276 staining. Normal appearing urothelium in the bladder of the same patients served as controls.

Results: The urothelial carcinoma cell lines expressed significantly higher levels of CD276 on transcript $(p<0.006)$, total protein levels $(p<0.005)$, and on the cell surface $(p<0.02)$ when compared to normal urothelial cells. In pT2-T4 tumor tissue samples, CD276 was overexpressed (median score 185) when compared to corresponding healthy tissues from the same patients (median score 50; $p<0.001$ ). No significant differences in CD276 expression were recorded in late, locally advanced $\geq$ pT3a tumors (median score 185) versus organ-confined $<$ pT3a tumors (median score 190), but it was significantly lower in the normal urothelial tissue associated with $\geq$ pT3a tumors (median score 40) versus $<$ pT3a tumors (median score 80; $p<0.05$ ).

Conclusion: CD276 expression is significantly elevated in urothelial carcinoma cells in all stages but varies between individuals considerably. Reduced CD276 expression in normal urothelial cells may imply that these cells would be protected from CD276-mediated immuno therapies.

Keywords: Urothelial carcinoma, Immune check-point protein, CD276, B7-H3, Bladder tumor stages

\section{Background}

Bladder cancer ranks among the most common malignancies. Despite efforts in cancer research, the 5-year survival rates between 1996-2004 (80\%) compared to 2008-2014 (77\%) have not improved [1]. Therefore,

\footnotetext{
*Correspondence: aicher@uni-tuebingen.de

${ }^{3}$ Department of Urology, Center for Medical Research, University of Tuebingen Hospital, Waldhoernlestrasse 22, 72072 Tübingen, Germany Full list of author information is available at the end of the article
}

additional tools for diagnosis and more effective therapies are urgently needed.

Recently active components to modulate immune responses have emerged as promising cancer therapies in bladder carcinoma [2]. These therapies mainly target the programmed death receptor 1 (PD-1) and its respective ligand PD-L1. PD1/PD-L1 immune checkpoint inhibitors have been approved in clinical settings for treatment of patients who are either cisplatin-refractory or cisplatinineligible based on the results of large phase II-III trials

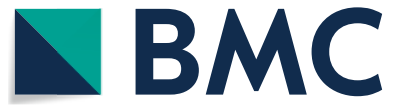

(c) The Author(s) 2021. This article is licensed under a Creative Commons Attribution 4.0 International License, which permits use, sharing, adaptation, distribution and reproduction in any medium or format, as long as you give appropriate credit to the original author(s) and the source, provide a link to the Creative Commons licence, and indicate if changes were made. The images or other third party material in this article are included in the article's Creative Commons licence, unless indicated otherwise in a credit line to the material. If material is not included in the article's Creative Commons licence and your intended use is not permitted by statutory regulation or exceeds the permitted use, you will need to obtain permission directly from the copyright holder. To view a copy of this licence, visit http://creativecommons.org/licenses/by/4.0/. The Creative Commons Public Domain Dedication waiver (http://creativecommons.org/publicdomain/zero/1.0/) applies to the data made available in this article, unless otherwise stated in a credit line to the data. 
[3-5]. Other immune checkpoint receptors have been described and represent additional promising targets for therapy.

One such attractive therapeutic target is CD276 (alias B7-H3) which is over-expressed in many tumors [6-8] and often correlates with poor prognosis [9-11]. CD276 is a member of the B7/CD28 family of antigen independent co-stimulatory ligands. In mice, CD276 binds to the triggering receptor expressed on myeloid cells like transcript 2 (TLT-2) protein to modulate T-cell responses [12]. Elevated expression of CD276 enhances the TLT2-mediated $\mathrm{CD}^{+}$cytotoxic T-lymphocyte response to tumor in mice [13]. In another study, CD276 prevented activation of anti-tumor responses by blocking $C D 4^{+} \mathrm{Th}_{1}$ activation [14]. There is experimental evidence promising success of anti-CD276 tumor therapies [6, 14-16], and several clinical studies are underway or already completed (see https://clinicaltrials.gov).

Targeting CD276 directly on tumor cells is a promising strategy [6]. Such targeting would require knowledge about the amount of receptor on the cells and its distribution in the tissue. It has been estimated that 2000 CD276 ligands would be required per tumor cell for such a targeted therapy to be effective [6]. In this context, the objective of this study was to study the expression levels of CD276 on well-characterized human urothelial cancer cell lines and in tissue samples from bladder tumors as a function of the tumor staging.

\section{Methods}

\section{Preparation and expansion of cells}

Urothelial cancer cell lines (UCCLs) HT1197 (CRL1473), TCCsup (HTB-5), RT4 (HTB-2), and 5637 (HTB9) were purchased from ATCC (www.atcc.org). They were expanded in MEM medium enriched with bovine serum, non-essential amino acids, sodium pyruvate and antibiotics as recommended by the supplier. Normal urothelial cells (NUCs) were prepared from cancer-free ureteral tissue samples from 4 donors after informed and written consent, and expanded as previously described [17]. The integrity of each NUC culture was confirmed by immunohistochemistry with the pancytokeratin marker cytokeratin AE1/AE3 (not shown). Contamination of cultures by mycoplasma were excluded by PCR analysis following established protocols (Biontex). The study was approved by the Ethics Committee under file number $341 / 2002 / B O$.

\section{Analysis of CD276 transcript and protein expression}

Cells were expanded to reach confluence, washed with cold PBS, detached by mild proteolysis, lysed to isolate RNA (Qiagen RNeasy kit), and cDNA was synthesized by reverse transcription and oligo $(\mathrm{dT})$ priming (Takara Bio).
Quantitative RT-PCR was performed employing CD276 target gene primers. GAPDH and PPIAy amplifications served as internal controls (Table 1) [18]. Proteins were detected in cell lysates after SDS-PAGE by immunoblotting (IB) [19] using monoclonal antibodies (mAb) or sera, followed by peroxidase-labelled secondary antibodies (Table 2), and quantified by a blot scanner (C-Digit, Licor). The CD276 signal intensities in each sample were normalized to $\beta$-actin signals of each sample.

\section{Analysis of CD276 expression on cell surfaces}

To quantify CD276 expression on UCCLs and NUCs, cells were grown to confluence, detached by mild proteolysis and washed twice by PBS. 5E05 cells were resuspended in PFEA buffer, incubated with anti-CD276 mAB and measured by flow cytometry (FC) as described (LSR II, Becton Dickinson) [20]. Staining of cells with a mAB to KLH served as isotype control (Table 2). Signal intensities were normalized to COMP-beads (Becton Dickinson) and the KLH isotype controls in each experiment.

\section{Detection of CD276 in paraffin sections of tissue microarrays}

Tissue microarrays (TMA) were assembled from $0.6 \mathrm{~mm}$ bladder tissue punches after radical cystectomy of $98 \mathrm{BC}$ patients after informed and written consent as described [21]. 98 tissue punches were obtained from pathologically confirmed tumor areas. In addition, from the same bladders, 47 tissue punches were prepared from tumor adjacent but healthy appearing areas, which were pathologically confirmed as normal tissue. For immunohistochemistry (IHC), TMA sections were incubated with anti-CD276 mAb $\left(1 \mathrm{~h}, 20{ }^{\circ} \mathrm{C}\right.$; Table 2$)$, washed three times with $0.1 \%$ Tween 120 in PBS and counterstained by OptiView DAB IHC detection kit as described by the supplier (Ventana, Roche, Switzerland). To confirm histology, samples were stained after IHC by hematoxylin and eosin (HE). Antibody staining intensities $($ no $=0$, weak $=1$, middle $=2$, strong $=3$ ) and the percent area of staining per TMA $(0-100 \%)$ were recorded by microscopy to generate scores ranging from " 0 " (no antibody

Table 1 Primers for quantitative RT-PCR

\begin{tabular}{lll}
\hline Gene & Primer & Sequence $\left(5^{\prime} \rightarrow 3^{\prime}\right)$ \\
\hline CD276 & Forward & TTTCCTTTCCCCTCC \\
& Reverse & TGTGACCAGCACATG \\
GAPDH & Forward & GAGTCAACGGATTTGGTCGT \\
& Reverse & TTGATTTTGGAGGGATCTCG \\
PPIAY & Forward & TTCATCTGCACTGCCAAGAC \\
& Reverse & TCGAGTTGTCCACAGTCAGC \\
\hline
\end{tabular}


Table 2 Antibodies to human antigens and detection reagents for immunoblotting (IB), flow cytometry (FC), and immunohistochemistry $(\mathrm{IHC})$

\begin{tabular}{|c|c|c|c|c|c|c|}
\hline Target & Antibody/label & Species & Clone & Dilution & Source & Order \# \\
\hline \multicolumn{7}{|l|}{ IB } \\
\hline CD276 & $\lg G 1 \mathrm{mAB}$ & Mouse & $6 \mathrm{~A} 1$ & $1: 600$ & abcam & ab105922 \\
\hline CD276 & serum & Rabbit & $\varnothing$ & $1: 500$ & abcam & ab226256 \\
\hline$\beta$ actin & serum & Rabbit & $\varnothing$ & $1: 1000$ & abcam & ab8227 \\
\hline Mouse lgG & serum/HRP & Rabbit & $\varnothing$ & $1: 2000$ & Dako & P0260 \\
\hline Rabbit lg & serum/HRP & Goat & $\varnothing$ & $1: 2000$ & Dako & 20034870 \\
\hline \multicolumn{7}{|l|}{$F C$} \\
\hline CD276 & $\lg \mathrm{G} 1 \mathrm{mAB} / \mathrm{PE}$ & Mouse & $\mathrm{MlH} 42$ & $1: 20$ & BioLegend & B7RP2 \\
\hline $\mathrm{KLH}$ & $\operatorname{lgG} 1 \mathrm{mAB} / \mathrm{PE}$ & Mouse & $X 40$ & $1: 20$ & $\mathrm{BD}$ & 345816 \\
\hline \multicolumn{7}{|l|}{ IHC } \\
\hline CD276 & $\operatorname{lgG1} \mathrm{mAB}$ & Mouse & $6 \mathrm{~A} 1$ & $1: 300$ & abcam & ab105922 \\
\hline
\end{tabular}

stain) to " 300 " (maximal staining intensity in the whole TMA) [21].

\section{Statistics}

Experimental results were processed by spreadsheet $\left(\right.$ Excel $^{\circledR}$, Microsoft) and statistics software $\left(\mathrm{JMP}^{\circledR}\right.$, SAS Institute Inc., Cary, USA). P values less than 0.05 were considered significant and marked in the figures accordingly.

\section{Results}

\section{Expression of CD276 in urothelial carcinoma cell lines} in vitro

Transcript amounts encoding CD276 were enumerated in UCCLs and NUCs by quantitative RT-PCR. CD276 mRNA was detected in both populations but the mean expression in the 4 UCCLs was significantly higher than in the 4 NUCs (threefold, $p<0.006$, Fig. 1a). Similarly, immunoblotting revealed a significantly higher expression of CD276 protein in UCCLs compared to NUCs (fivefold, $p<0.005$, Fig. 1b). The mean fluorescence intensity (MFI) of cell surface CD276 expression as determined by flow cytometry was increased 3.7 -fold in UCCLs (MFI: 13,302 \pm 2163 ) when compared to NUCs (MFI: 3591 $\pm 2080 ; p<0.012$; Fig. 2).

\section{Expression of CD276 in bladder tumor tissue samples}

Tissue microarrays (TMA) were assembled from samples of 28 stage pT2, 46 stage pT3, 23 stage pT4 tumors and one additional $\mathrm{BC}$ tumor sample with unknown stage. The clinical and pathologic characteristics of the patient cohort are summarized in Table 3. Paraffin sections from tissue samples of these patients were stained with anti-CD276 antibody to determine the expression pattern of this immune checkpoint protein (Fig. 3). CD276 expression was found in urothelial cells but not in the

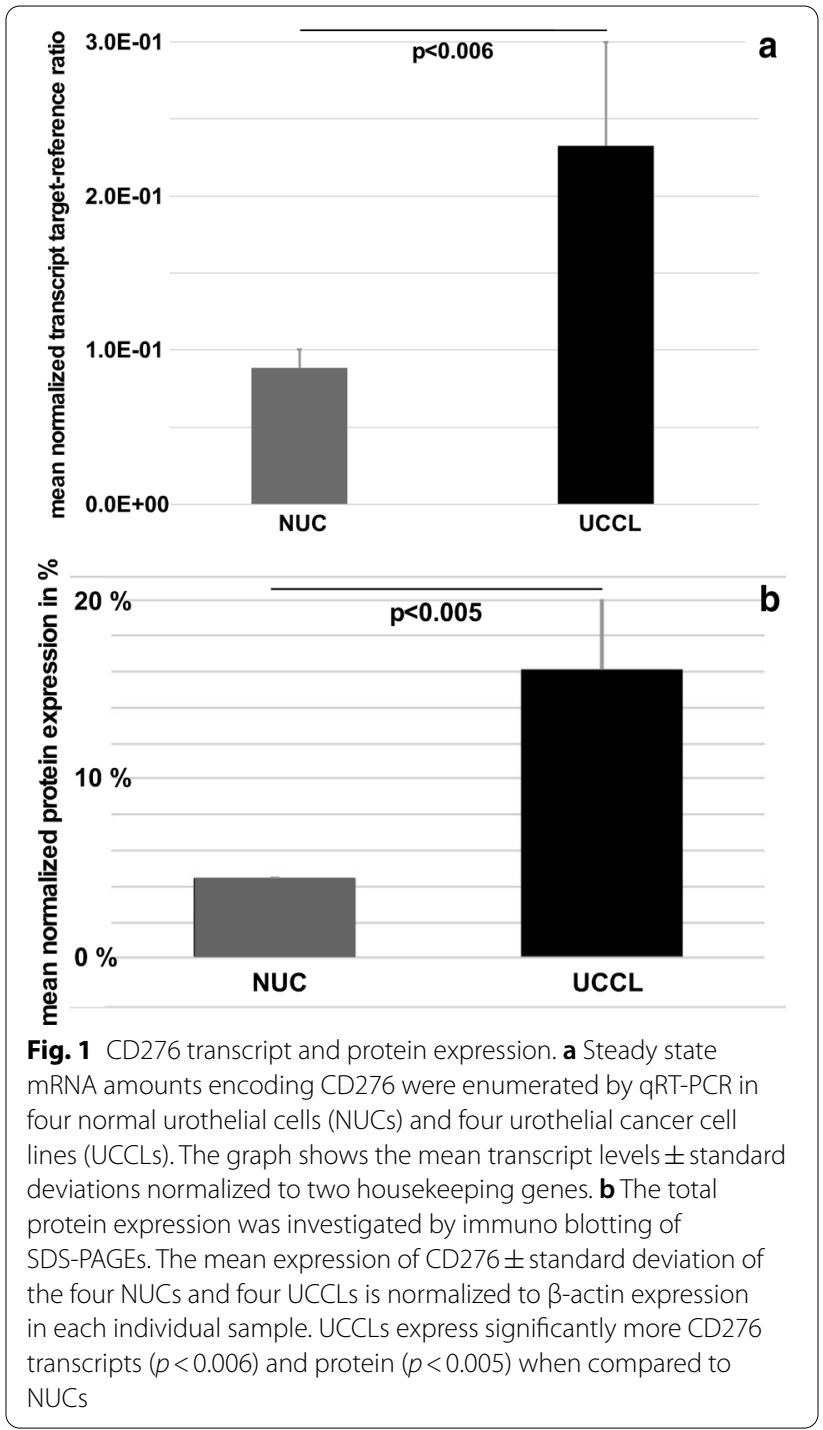



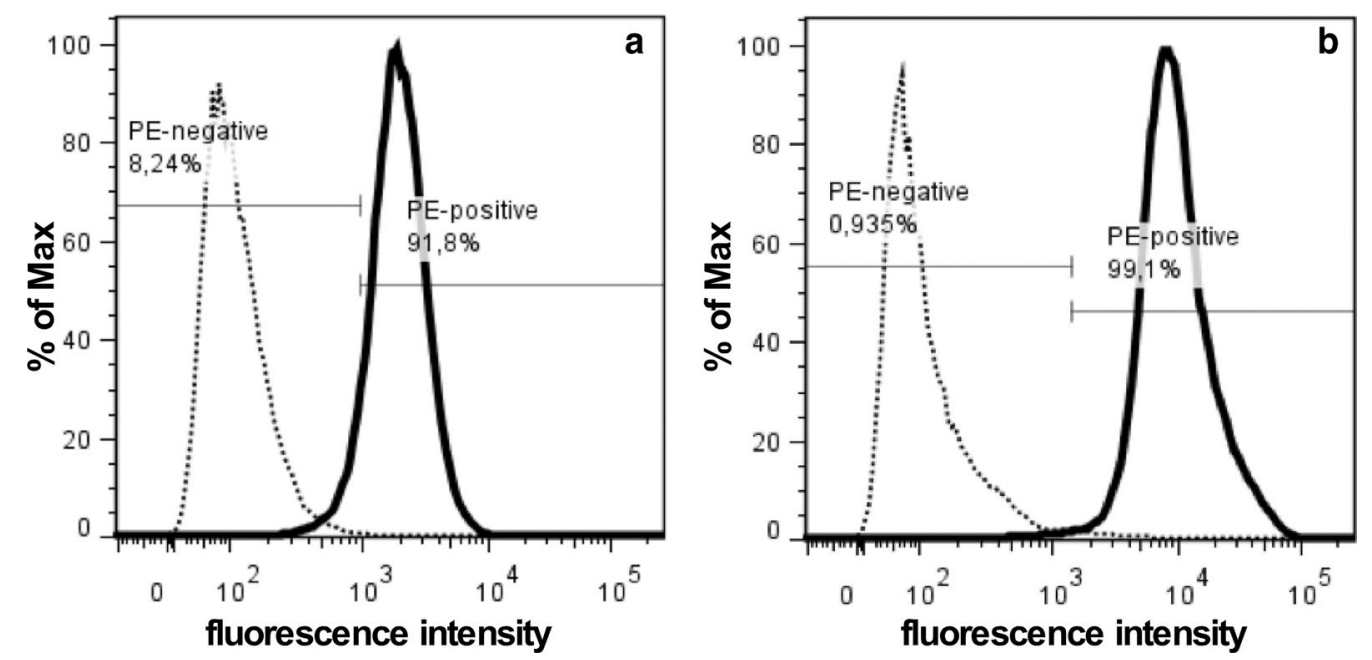

Fig. 2 Cell surface expression of CD276. The density of CD276 on cell surfaces was enumerated by flow cytometry on normal urothelial cells (NUCs) and urothelial cancer cell lines (UCCLs). a The representative NUC (HL19/17) shows a mean fluorescence intensity (MFI) of 2E03 and $91.8 \%$ of cells were gated positive for CD276 (solid histogram). b The representative tumor cell line HT1 197 shows a MFI of 1.12E04 and 99.1\% of cells were gated CD276 positive. Dotted histograms present isotype controls. The $x$-axis denotes the fluorescence intensity, the Y-axis the number of cells recorded as $\%$ of the maximum

connective tissue layers of histologically normal appearing bladder in bladder cancer patients (Fig. 3a). Low and dispersed CD276 expression was noted in some tumor samples (Fig. 3b), while its expression was high in other tumor samples (Fig. 3c). When comparing CD276 expression in healthy versus tumor tissue obtained from the 98 patient's bladders, its median expression was significantly lower in normal appearing tissue surrounding the tumors (score $50, \mathrm{n}=47$ ) when compared to the bladder tumors themselves (score 185, $\mathrm{n}=98 ; p<0.0001$, Fig. 4). However, the CD276 expression scores were quite variable in both areas, in the tumors as well as the surrounding benigne tissue: the benign samples scored between 0 and 160, and tumor samples scored between 0 and 300 .

However, the range of the CD276 score of benign samples surpassed the lowest quartile of the range of CD276 scores of the tumor samples (i.e., score 125) in only 3 of 47 cases (i.e., in 6.3\%). In 12 of 47 benign samples (25\%) CD276 expression was not observed at all (Fig. 4). Only 8 of 98 BC tumor samples (8.1\%) scored within the range of the 3 lower quartiles of the benign samples (i.e., score < 90; Fig. 4).

When correlating the CD276 expression to the tumor stage, elevated expression was found in all bladder tumor stages from T2a to T4b (Fig. 5a) when compared to the median expression score of normal appearing urothelial samples from the same patients (Fig. 4). The peak median expression intensity of 210 was measured in samples obtained from pT2b tumors (Fig. 5a). No significant differences were observed in CD276 expression when comparing organ-confined $(<\mathrm{pT} 3 \mathrm{a}$, median score 190 ) with locally advanced tumors ( $\geq$ pT3a, median score $185 ; X^{2}=0.86$; Fig. $5 B$ ). However, a significant drop in the mean expression of CD276 was noted in the histologically normal tissue samples when stratified by the $\mathrm{T}$ stage of the tumor in the same specimen $(<\mathrm{pT} 3 \mathrm{a}$ vs. $\geq \mathrm{pT} 3 \mathrm{a}$, $p<0.042$; Fig. 6). The median score of CD276 expression dropped from 80 in benign urothelium from $<$ pT3a patients to 40 in stage $\geq$ pT3a samples (Fig. 6).

\section{Discussion}

Elevated expression of CD276 in bladder cancer samples was reported previously [22] and success of experimental anti-CD276 antibody therapies raised hope for a new immune checkpoint therapy $[6,15,16]$. Our in vitro data using the well-established bladder cancer cell lines HT1197, TCCsup, RT4, and 5637 in comparison to four urothelial cell populations generated from explants from healthy ureters corroborated a significant overexpression of CD276 in BC cell lines. Significant overexpression of CD276 was also noted by immunohistochemistry in bladder tumors samples when compared to benign urothelium obtained from the same bladders. Slightly elevated CD276 scores in benigne samples from earlystage $\mathrm{BC}$ tumor patients could be caused by a moderate activation of CD276 expression in a few cells surrounding the tumor without showing the typical histology of a BC tumor by microscopy. CD276 transcript analyses of the corresponding malignant and benigne areas of $\mathrm{BC}$ samples could explore this hypothesis. Of note, healthy 
Table 3 Patient characteristics

\begin{tabular}{|c|c|}
\hline $\mathrm{BC}$ patients & 98 total \\
\hline Tumor samples—n (\%) & $98(100.0)$ \\
\hline Benigne samples-n (\%) & $47(100.0)$ \\
\hline \multicolumn{2}{|l|}{ Gender-n (\%) } \\
\hline Female & $23(23.5)$ \\
\hline Male & $75(76.5)$ \\
\hline \multicolumn{2}{|l|}{ Age, years } \\
\hline Median (range) & $69(32-84)$ \\
\hline \multicolumn{2}{|l|}{ pT-Stage-n (\%) } \\
\hline $2 a$ & $15(15.5)$ \\
\hline $2 b$ & $13(13.6)$ \\
\hline 3а & $22(22.7)$ \\
\hline $3 b$ & $24(24.7)$ \\
\hline $4 a$ & $17(17.5)$ \\
\hline $4 b$ & $6(6.2)$ \\
\hline Unknown & 1 \\
\hline \multicolumn{2}{|l|}{ Grading-n (\%) } \\
\hline 1 & 0 \\
\hline 2 & $23(23.5)$ \\
\hline 3 & $75(76.5)$ \\
\hline \multicolumn{2}{|l|}{ Concomitant CIS—n (\%) } \\
\hline Yes & $28(30.1)$ \\
\hline No & $65(69.9)$ \\
\hline Unknown & 5 \\
\hline \multicolumn{2}{|l|}{ cN-Stage-n (\%) } \\
\hline 0 & $56(59.5)$ \\
\hline 1 & $23(24.5)$ \\
\hline 2 & $13(13.7)$ \\
\hline 3 & $2(2.3)$ \\
\hline Unknown & 4 \\
\hline \multicolumn{2}{|l|}{ cM-Stage-n (\%) } \\
\hline 0 & $85(90.4)$ \\
\hline 1 & $9(9.6)$ \\
\hline Unknown & 4 \\
\hline \multicolumn{2}{|l|}{ R-Stage-n (\%) } \\
\hline 0 & 80 (81.6) \\
\hline 1 & $15(15.3)$ \\
\hline 2 & $3(3.1)$ \\
\hline
\end{tabular}

bladder tissue from healthy volunteers was not available. Therefore, mechanisms of CD276 regulation in normal appearing tissue surrounding tumors versus healthy tissue are beyond the focus of the current study.

When analyzing the association between CD276 expression and tumor stage by immunohistochemistry in sample subsets, the highest median scores were observed in T2b and T3a tumors, followed by a minor, non-significant decline in higher stages (T3b and T4). In contrast, in benign urothelium from samples of patients with later stage tumors $(\geq \mathrm{T} 3 \mathrm{a})$ mean $\mathrm{CD} 276$ was significantly reduced when compared to benign sites in sample from patients with early-stage tumors (<T3a).

Expression of CD276 in bladder tissue samples from cancerous and adjacent healthy areas was determined by immunohistochemistry but not, for instance, by transcriptomics or other molecular analyses. Therefore, the mechanisms contributing to the significant changes in CD276 expression in situ in the normal tissue remained obscure. Total protein expression is often regulated on the transcript level and tumor grade-depended elevation of CD276 transcripts and CD276 total protein were found in $\mathrm{BC}$ [22]. However, other mechanisms may contribute to the changes in CD276 expression observed as well. For instance, protease-mediated release of soluble CD276 was described on activated leukocytes [23]. Blocking the protease activity caused an accumulation of CD276 on these leukocytes [23]. Based on this finding we hypothesize that elevated expression of proteases by the bladder tumor cells may play a role in degradation of even little CD276 from the surface of the benign cells surrounding the actual tumor. This mechanism may act on bladder tumors as well, and thereby contribute to the minor reduction of the mean CD276 score observed in the pT4 samples. This hypothesis is in line with the finding that elevated expression of CD276 correlated with elevated expression of matrix metalloproteinases -2 and-9 [22].

We noted considerable variations of CD276 expression in individual samples from all stages of bladder tumors. This may be in part associated with changes in cell surface versus cytoplasmic expression of CD276. Such a conversion of CD276 expression has been observed in clear cell renal cell carcinoma [24]. Tumors with pronounced cytoplasmic expression were associated with worse prognosis when compared to those with membrane expression. But degradation of CD276 by proteases as mechanism to generate the cytoplasmic CD276 phenotype was not investigated in that study [24]. In other studies, tumor therapy by a PD-1 inhibitor reduced the expression of CD276 on bladder cancer carcinoma cells significantly in about $67 \%$ of samples investigated [25]. These findings indicated that CD276 expression may change its levels and patterns during the course of disease and/or depending on the therapy. However, the patients included in our study were not treated by immune checkpoint inhibitors.

A technical challenge is of course the fact that histology yields in many cases the sum of protein expression in the cytoplasm and on the cell surface. For the interaction with $\mathrm{T}$ lymphocytes as well as the direct binding of anti-CD276 antibodies or alike, the presentation of CD276 on the cells surface is critical. Therefore, additional studies need to determine the correlation 

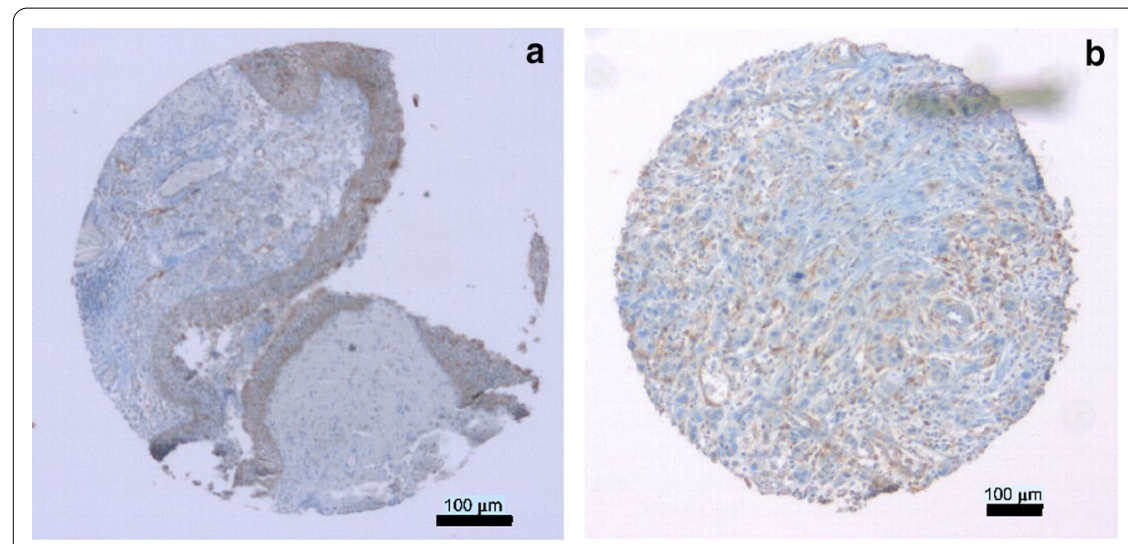

b

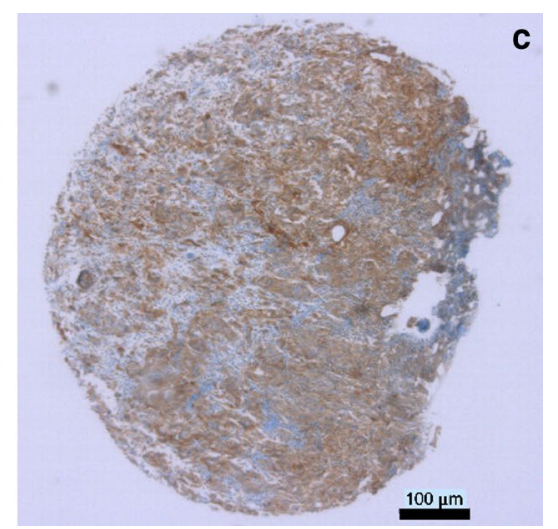

Fig. 3 Detection of CD276 in tissue samples by immunohistochemistry. Representative tissue samples of benign urothelium (a), low expressing tumor tissue (b) and high expressing tumor tissue (c) were assessed for expression of CD276 on a tissue microarray by immunohistochemistry. Sections were counterstained with hematoxylin and eosin to visualize tissue structure. Size bars $=100 \mu \mathrm{m}$

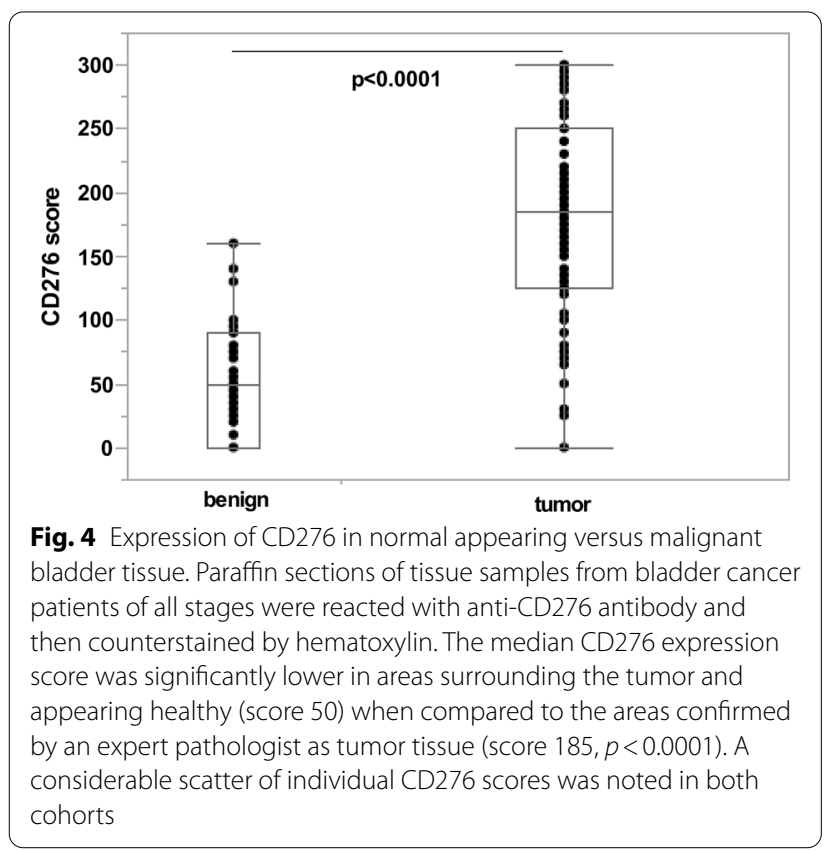

between total protein expression in bladder tumor tissue in comparison to the CD276 density on tumor cell surfaces $[22,24,25]$.

\section{Conclusions}

Median expression of CD276 is significantly elevated in bladder carcinoma tissue but presents with a high interindividual variability among patient samples. Diagnosis or therapy utilizing CD276 as target molecule should therefore be considered and evaluated with care, especially in late-stage patients.

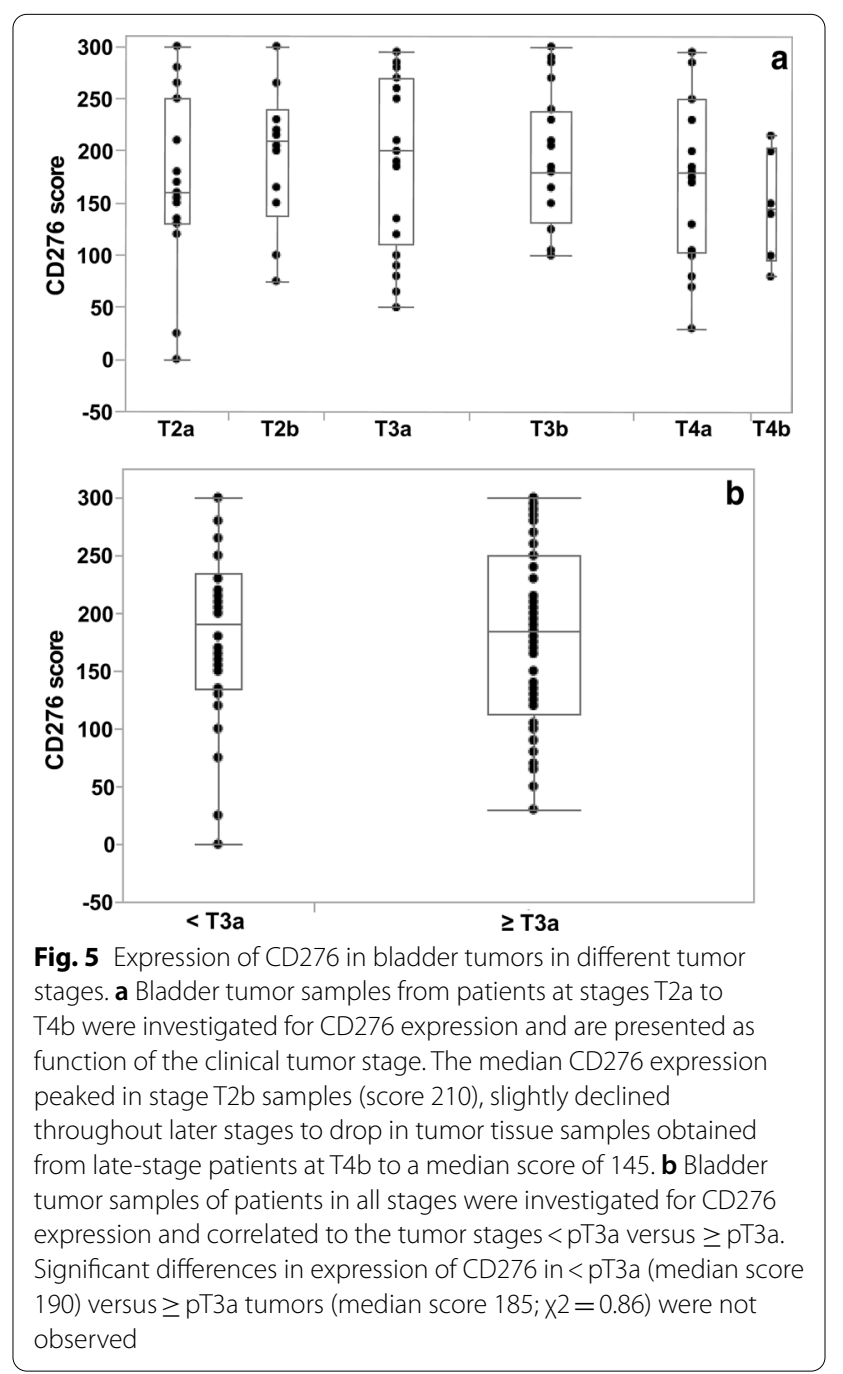




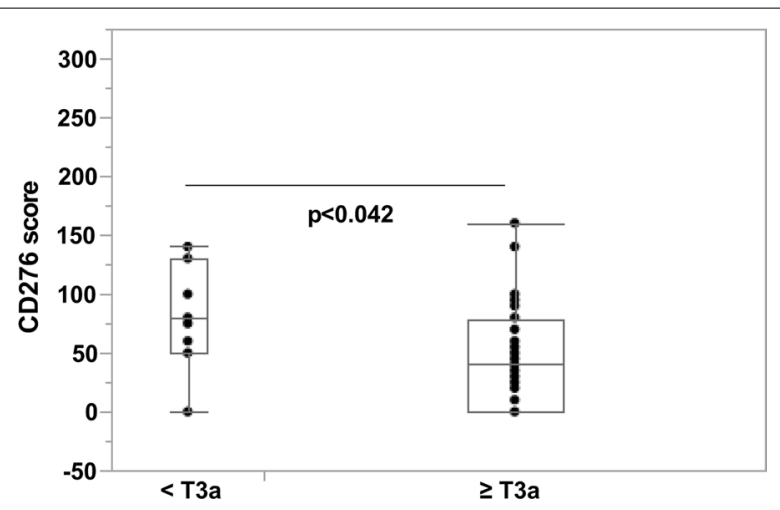

Fig. 6 CD276 expression in normal appearing urothelium from bladder tumor patients. Expression of CD276 was evaluated by immunohistochemistry in areas presenting with normal histology and samples obtained from patients at earlier $(<\mathrm{pT} 3 \mathrm{a}$ ) versus later T stages ( $\geq$ pT3a) were compared. In confirmed normal urothelium from patients of tumor stages $<$ pT3a, CD276 expression scored with a median of 80. In confirmed normal urothelium from tumor patients at stages $\geq$ PT3a CD276 dropped significantly to a median of 40

\section{Abbreviations}

BC: Bladder cancer; FC: Flow cytometry; HRP: Horse reddish peroxidase; IB: Immunoblot, alias Western blot; IHC: Immunohistochemistry; KLH: Keyhole limped hemocyanin; mAB: Monoclonal antibody; MFI: Mean fluorescence intensity; NUCs: Normal urothelial cells; TMA: Tissue micro array; UCCL: Urothelial carcinoma cell line.

\section{Acknowledgements}

The authors express their gratitude to T. Neumann for expert help with statistics, Conny Bock and Tanja Abruzzese for excellent technical support and training of the students, A. Knoll for support of NUC analyses, Falko Fend for sharing expertise in pathology, and Chaim Goziga for support in preparation of the figures.

\section{Authors' contributions}

WKA, AS: study design, supervision, data evaluation, manuscript writing; MK, $L R$, FBM: lab experiments, data evaluation; JH, PCB, TT, JB: providing tumor sample or cell lines, data evaluation, manuscript writing; WKA, AS, TT: funding.

\section{Funding}

This study was supported in part by grants to S.A. and T.T. from the AdolfLeuze-Stiftung, Stiftungsnetzwerk Region Stuttgart e.V. Owen, Germany and in part by institutional funds.

\section{Availability of data and materials}

Data generated in this study are available from the corresponding author on reasonable request.

\section{Declarations}

\section{Ethics approval and consent to participate}

The study was performed employing samples from patients after informed and written consent in accordance with the Declaration of Helsinki. It was approved by the Ethics Committee of the University of Tübingen Hospital (UKT) and the Eberhard-Karls-University Tübingen (EKUT) under File Number 341/2002. The study was undertaken in the Department of Urology at UKT All experiments were performed in accordance with relevant guidelines and regulations.

\section{Consent for publication}

In vitro study, $\varnothing$, not applicable.

\section{Competing interest}

The authors declare that (1) they do not have any competing interests, and that (2) this study and all parts of it have not been published yet, nor are they considered for or submitted for publication anywhere else. All authors have seen the manuscript and agree with its publication in BMC Urology.

\section{Author details}

${ }^{1}$ Department of Urology, University of Tuebingen Hospital, Hoppe-Seyler-Str. 3, 72076 Tübingen, Germany. ${ }^{2}$ Vancouver Prostate Centre, University of British Columbia, Level 6, 2775 Laurel St, Vancouver, BC V5Z 1M9, Canada. ${ }^{3}$ Department of Urology, Center for Medical Research, University of Tuebingen Hospital, Waldhoernlestrasse 22, 72072 Tübingen, Germany.

Received: 15 December 2020 Accepted: 1 April 2021

Published online: 12 April 2021

\section{References}

1. Siegel RL, Miller KD, Jemal A. Cancer statistics, 2019. CA Cancer J Clin. 2019;69(1):7-34.

2. Sharpe AH. Introduction to checkpoint inhibitors and cancer immunotherapy. Immunol Rev. 2017;276(1):5-8.

3. Sharma P, Retz M, Siefker-Radtke A, Baron A, Necchi A, Bedke J, Plimack ER, Vaena D, Grimm M-O, Bracarda S, et al. Nivolumab in metastatic urothelial carcinoma after platinum therapy (CheckMate 275): a multicentre, single-arm, phase 2 trial. Lancet Oncol. 2017;18(3):312-22.

4. Balar AV, Galsky MD, Rosenberg JE, Powles T, Petrylak DP, Bellmunt J, Loriot Y, Necchi A, Hoffman-Censits J, Perez-Gracia JL, et al. Atezolizumab as first-line treatment in cisplatin-ineligible patients with locally advanced and metastatic urothelial carcinoma: a single-arm, multicentre, phase 2 trial. The Lancet. 2017;389(10064):67-76.

5. Bellmunt J, de Wit R, Vaughn DJ, Fradet Y, Lee J-L, Fong L, Vogelzang NJ, Climent MA, Petrylak DP, Choueiri TK, et al. Pembrolizumab as second-line therapy for advanced urothelial carcinoma. N Engl J Med. 2017;376(11):1015-26.

6. Seaman $S$, Zhu Z, Saha S, Zhang XM, Yang MY, Hilton MB, Morris K, Szot C, Morris $\mathrm{H}$, Swing DA, et al. Eradication of tumors through simultaneous ablation of CD276/B7-H3-positive tumor cells and tumor vasculature. Cancer Cell. 2017;31(4):501-515.e508.

7. Dong $\mathrm{P}$, Xiong $\mathrm{Y}$, Yue J, Hanley SJB, Watari H. B7H3 as a promoter of metastasis and promising therapeutic target. Front Oncol. 2018:8:264.

8. Li P, Yang Y, Jin Y, Zhao R, Dong C, Zheng W, Zhang T, Li J, Gu Z. B7-H3 participates in human salivary gland epithelial cells apoptosis through NF-KB pathway in primary Sjögren's syndrome. J TransI Med. 2019;17(1):268.

9. Xylinas E, Robinson BD, Kluth LA, Volkmer BG, Hautmann R, Kufer R, Zerbib M, Kwon E, Thompson RH, Boorjian SA, et al. Association of T-cell co-regulatory protein expression with clinical outcomes following radical cystectomy for urothelial carcinoma of the bladder. Eur J Surg Oncol. 2014;40(1):121-7.

10. Ye Z, Zheng Z, Li X, Zhu Y, Zhong Z, Peng L, Wu Y. B7-H3 overexpression predicts poor survival of cancer patients: a meta-analysis. Cell Physiol Biochem. 2016:39(4):1568-80.

11. Xu ZL, Zhang Y, Wang L, Li F, Man HW, Li PF, Shan BE. B7-H3 promotes malignant progression of muscle-invasive bladder cancer. Oncol Rep. 2018;40(5):2722-33.

12. Loos M, Hedderich DM, Friess $\mathrm{H}$, Kleeff J. B7-H3 and its role in antitumor immunity. Clin Dev Immunol. 2010;2010:683875.

13. Kobori H, Hashiguchi M, Piao J, Kato M, Ritprajak P, Azuma M. Enhancement of effector CD8 + T-cell function by tumour-associated B7-H3 and modulation of its counter-receptor triggering receptor expressed on myeloid cell-like transcript 2 at tumour sites. Immunology. 2010;130(3):363-73

14. Suh WK, Gajewska BU, Okada H, Gronski MA, Bertram EM, Dawicki W, Duncan GS, Bukczynski J, Plyte S, Elia A, et al. The B7 family member B7-H3 preferentially down-regulates $\mathrm{T}$ helper type 1-mediated immune responses. Nat Immunol. 2003;4(9):899-906.

15. Lee YH, Martin-Orozco N, Zheng P, Li J, Zhang P, Tan H, Park HJ, Jeong M, Chang SH, Kim BS, et al. Inhibition of the B7-H3 immune checkpoint 
limits tumor growth by enhancing cytotoxic lymphocyte function. Cell Res. 2017;27(8):1034-45.

16. Ma W, Ma J, Ma P, Lei T, Zhao M, Zhang M. Targeting immunotherapy for bladder cancer using anti-CD3x B7-H3 bispecific antibody. Cancer Med. 2018;7(10):5167-77.

17. Nagele U, Maurer S, Feil G, Bock C, Krug J, Sievert K-D, Stenzl A. In vitro investigations of tissue-engineered multilayered urothelium established from bladder washings. Eur Urol. 2008;54(6):1414-22.

18. Pfaff MW. Quantification strategies in real-time PCR. In: Bustin SA, editor A-Z of quantitative PCR. La Jolla, CA: International University Line; 2004. p. $87-112$.

19. Ausubel FM, Brent R, Kingston RE, Moore DD, Seidman JG, Smith JA, Struhl K. Short protocols in molecular biology. New York: Wiley; 2002.

20. Pilz GA, Braun J, Ulrich C, Felka T, Warstat K, Ruh M, Schewe B, Abele H, Larbi A, Aicher WK. Human mesenchymal stromal cells express CD14 cross-reactive epitopes. Cytometry A. 2011;79(8):635-45.

21. Semilia M, Hennenlotter J, Pavone C, BischoffT, Kuhs U, Gakis G, Bedke J, Stenzl A, Schwentner C, Todenhofer T. Expression patterns and prognostic role of transketolase-like 1 in muscle-invasive bladder cancer. World J Urol. 2015;33(10):1403-9.

22. Li Y, Guo G, Song J, Cai Z, Yang J, Chen Z, Wang Y, Huang Y, Gao Q. B7-H3 promotes the migration and invasion of human bladder cancer cells via the PI3K/Akt/STAT3 signaling pathway. J Cancer. 2017;8(5):816-24.
23. Zhang G, Hou J, Shi J, Yu G, Lu B, Zhang X. Soluble CD276 (B7-H3) is released from monocytes, dendritic cells and activated $T$ cells and is detectable in normal human serum. Immunology. 2008;123(4):538-46.

24. Saeednejad Zanjani L, Madjd Z, Axcrona U, Abolhasani M, Rasti A, Asgari $\mathrm{M}$, Fodstad $\tilde{A}$, Andersson Y. Cytoplasmic expression of B7-H3 and membranous EpCAM expression are associated with higher grade and survival outcomes in patients with clear cell renal cell carcinoma. Ann Diagn Pathol. 2020;46:151483.

25. Necchi A, Anichini A, Raggi D, Briganti A, Massa S, Luciano R, Colecchia M, Giannatempo P, Mortarini R, Bianchi M, et al. Pembrolizumab as neoadjuvant therapy before radical cystectomy in patients with muscle-invasive urothelial bladder carcinoma (PURE-01): an open-label, single-arm, phase II study. J Clin Oncol. 2018;36(34):3353.

\section{Publisher's Note}

Springer Nature remains neutral with regard to jurisdictional claims in published maps and institutional affiliations.
Ready to submit your research? Choose BMC and benefit from:

- fast, convenient online submission

- thorough peer review by experienced researchers in your field

- rapid publication on acceptance

- support for research data, including large and complex data types

- gold Open Access which fosters wider collaboration and increased citations

- maximum visibility for your research: over 100M website views per year

At BMC, research is always in progress.

Learn more biomedcentral.com/submissions 